Серед кінематографічних прийомів роману Ю. Винничука жанрові елементи містики [1, с. 8], [1, с. 19], [1, с. 301-302], [1, с. 295], сюжетна лінія про Львівську математичну школу і «Шкоцьку» книгу наукові відкриття якої випереджають епоху [1, с. 92], легенда про лева коло ратуші $[1$, с. 140], що створюють емоційне забарвлення, урізноманітнюють загальну жанрову тематику мета- чи параісторії.

\title{
Література:
}

1. Винничук Ю. Цензор снів. Харків: Фоліо, 2017. 365 с.

2. Гершевська Б. 3 історії культури кіно у Львові 1918-1939 pp. Львів, Бібліотека журналу «Ї», 2004. 100 с.

3. Шкловский В. О Дзыге Вертове. Дзыга Вертов в воспоминаниях современников. М.: Искусство, 1976. С. 171-183. URL: https://chapaev.media/articles/9984 (дата звернення: 20.12.2020).

4. Щербенок А. Дзига Вертов: диалектика киновещи. Искусство кино. 2012. №1. URL: http://old.kinoart.ru/archive/2012/01/dziga-vertovdialektika-kinoveshi) (дата звернення 25.12.2020).

DOI https://doi.org/10.30525/978-9934-26-039-1-31

\section{ОБРАЗ ВІЙНИ У РОМАНІ ТАМАРИ ГОРІХА ЗЕРНЯ «ДОЦЯ»}

\author{
Присівок Д. В. \\ аспірант кафедри української літератури, \\ методики ї̈ навчання та журналістики \\ Ніжинського державного університету імені Миколи Гоголя \\ м. Ніжин, Чернігівська область, Україна
}

Серед маси текстів про війну більшість має чоловіче авторство. Проте, існують твори, написані жінками і відзначені літературними та мистецькими преміями, зокрема роман Тамари Горіха Зерня «Доця», який отримав нагороду «Книга року ВВС-2019». Авторка у своєму романі представляс жіночий погляд на війну, який важливо враховувати для цілісного розуміння візії війни у літературі.

Розповідь у книзі ведеться від першої особи - жінки на прізвисько «Доця». Ім'я головної героїні не називається. Авторка говорить про цей прийом так: «Це зроблено для того, щоб створити для читача ефект присутності. Мені потрібно, щоб людина, яка читатиме ставила себе на місце головної героїні» [2]. 
У Доці є містичні жіночі риси. Вона проявляє себе як активний борець із несправедливістю нового режиму, який прийшов на схід України, проте бореться вона по-своєму. Доця - це жінка-берегиня: відразу з початком заворушень у Донецьку вона захищає, підтримує, шукає кого можна врятувати, вимолює, витягує з того світу, іiі не цікавлять хлопці (загалом тілесності вона приділяє мало уваги), а голод готова вгамовувати простою кашею з тушонкою, таким чином вона проявляє себе як захисниця, а часом відьма, «шептуха». Проте, оглядачі помітили у образі головної героїні євангельські риси. Т. Петренко дає своїй рецензії назву «Ісусе, синку: «Доця» як месія з Донбасу» [3]. На думку критикині, Доця - це жіночий аналог Ісуса, який дає Донбасу надію на спасіння.

Прихід війни розділяє світ Доці на «до та після», а людей, які іï оточують, на два табори. Саме «розділення» ми вважаємо основною характеристикою образу війни у романі Тамари Горіха Зерня.

Доці важко бачити людей, з якими вона жила у одному місті: «Вони вірили у правий сектор, бандерівців, чупакабру і десант марсіан. Києва нема, він лежить у руїнах. Американські диверсанти отруїли воду... Столична влада наказала підірвати шахти і затопити Донецьк» [1, с. 51]. Різкий початок протестів відразу розділив людей на групи 3 протилежними поглядами.

Показуючи, як жителі східних областей із готовністю повірили у поширювану дезінформацію, авторка розкриває війну як поле для махінацій. Для захоплення невипадково були обрані території східної України. Авторка пояснює їхній вибір для утворення так званих «народних республік» через слова Тетяни: «Ми тут завжди були ніби і при Україні, а ніби в чужі вікна заглядаємо. От у вас що там водиться? Кутя, колядки, вертеп, так? І вишиванки, і мова і традиції... А для нас це все як зелений виноград - i хочеться і колеться» [1, с. 135]. Тобто те, що жителі Донбасу ніколи в повній мірі не відчували себе частиною України, стало можливістю для ворога поширювати тут пропаганду. Авторка досить документально, як для художнього твору, описує події, що відбувалися у місті і доводить, що сторона Росії готувалася до захоплення територій: на вулицях з'явилися групи підозрілих людей, на велику кількість мирних протестувальників нападали добре підготовлені люди зі зброєю, були підкуплені низові маргінальні верстви населення, правоохоронці не чинили опору, так само як і обласна та міська адміністрації, а в потрібний момент у місті з'явилися війська.

У ході розвитку сюжету навколо Доці формується кістяк людей, яким вона довіряє i, які готові боротися проти загарбників, а декого вона 
відсіює, наприклад, Марину, Комара, продавця з «еbау», який торгував обладнанням на обидва фронти. Знайшовши союзників, Доця починає боротьбу з новим режимом. Вона не іде воювати зі зброєю, а починає підтримувати тих, хто цього потребує. Рятує Аню, дочку Тетяни, 3 полону бойовиків, готує їжу для українських військових, збирає гроші для потреб армії і купує необхідне обладнання. Тут знову варто звернути увагу на документальність тексту, оскільки авторка показує не лише підготовку ворога, а і поганий, на той час, стан підтримки державою української армії, а також те, що протести трималися на самих активістах, не отримуючи державної підтримки, і врешті захлинулися. Розуміння величини прірви між окупантами та українськими військами додає Доці бажання займатися волонтерством.

Під час поїздок до солдатів біди дивним чином обминають Доцю та іiі команду, а коли вона знаходиться на заставах, не відбуваються обстріли. Це доповнює іï образ жінки-берегині, що бореться з загарбниками допомогою своїм союзникам.

У ході розвитку сюжету «розділення» війною поглиблюється. Авторка зображує «ополченців» безжальними, тож більшій кількості персонажів стає зрозуміло, що для них немає «своїх», бо вони 3 однаковою зневажливістю ставляться до всіх жителів міста, навіть до лояльних, про що свідчить епізод із бабою Степою: «Закрили на заводі на три дні. Не давали спати, ні разу не погодували, тримали в підвалі, а зрештою викинули в чому стояла, без авто, грошей і документів» [1, с. 255]. Доця ж і їі оточення, зі свого боку, ставляться поблажливо навіть до тих, хто має якісь зв'язки з Росією. Такими людьми є робітники 3 російської радіостанції, пенсіонери, що чекають визволення від Путіна, Комар.

Цілий район, де живе головна героїня, спустошується і відрізається від частини міста, де продовжують працювати магазини, заклади відпочинку тощо. Проте жителі міста періодично приїжджають на район i обкрадають квартири, продають чуже майно. Жителі ж району задовольняються пшоняною кашею 3 тушонкою, яку готує Доця, та водою $з$ колонки, а вечорами співають українських пісень. Таким способом, закріплюючи групи людей за певними територіями, авторка показує втрату людяності та відсутність чітких моральних орієнтирів у жителів міста, які підтримують новий порядок та, навпаки, готовність терпіти збитки тих, хто живе на околицях та підтримує Україну.

Також, аналізуючи війну як «розділення» у «Доці», варто зазначити, що для головної героїні відбувся не лише поділ людей, а й розділення часу на «до і після». Головним інструментом для зображення цього 
процесу виступає смерть. Переломним для Доці стає момент, коли під час демонстрації, яку мала захищати міліція, дістає важке поранення один із ії учасників і гине у кареті швидкої у Доці на очах. Після цього епізоду навколо жінки розвертається мертва, воєнна реальність. У той же вечір, зайшовши у бар, Доця проявляє свої відьомські здібності і бачить усіх відвідувачів мертвими: «...баба розповідала про «маску смерті». Мовляв, знаюча людина може помітити ознаки смерті за три дні до самої загибелі... Увесь бар, і відвідувачі, і офіціанти були мертвими» [1, с. 67]. Здібності відунки підштовхують дівчину до боротьби з загарбниками, про яку ми уже говорили вище. Займаючись цією справою, вона кілька разів ледь не гине і з кожним разом епізоди, що ілюструють війну як смерть, стають все більш жорстокими, а вороги набувають звірячих рис.

Смерть у романі виступає у ролі точки неповернення. Для головної героїні після смерті немає нічого, а вагу має лише життя. Найбільш шокуючими для героїні $є$ три мортальні моменти.

Під час першого Доця з Романом натикаються на вантажівку, що переслідується гвинтокрилом, перевертається і з неї випадають російські солдати, а навкруги розлітаються частини їхніх тіл. Щоб показати смертельність війни, авторка не нехтує використанням кривавих епізодів, відверто зображуючи пошматовані тіла.

Другий епізод - сцена 3 жінкою, на земельну ділянку якої падали тіла людей з підбитого літака: «- 3 неба люди падали. У мене на сараї. I на городі лежать. Голі, всі голі. I ноги кругом... В останні секунди я здивувалася, що смерть така проста» [1, с. 219]. Головна героїня приходить до думки, що в умовах війни людина нічого не важить, гинуть навіть ті, хто не має до неї стосунку.

Третій - епізод зі смертю Романа, Тетяни та Борисовича. До цього моменту гинули ті, хто не був їй настільки близьким, але тепер померли найближчі їй люди. Важливий цей момент тим, що він відображає остаточне розділення на «до і після». Тепер для Доці неважливе минуле $\mathrm{i}$ це передається через недоговорену фразу Борисовича: «І ти, доця. Я ж знаю про мамку твою, я знаю, що там...» [1, с. 280]. Ї̈̈ обірваність символізує те, що минулого для Доці нема i жінку вже не хвилює, що колись сталося 3 мамою, для неї тепер має вагу лише теперішнє і майбутнє.

Отже, у романі Тамари Горіха Зерня «Доця» війна представлена як сила, що розділяє людей на різні табори. Це відбувається через оприявлення прихованих рис людської натури. В одному випадку це підлість та егоїзм, у іншому рішучість та бажання допомагати. Другим аспектом цього розділення $\epsilon$ анулювання минулого, тобто поділ на «до та 
після». На думку головної героїні, не можна повернути минулого, але $\epsilon$ надія на майбутнє, яка представлена на останніх сторінках роману. Але для того, щоб майбутнє настало, потрібна боротьба, яка втілена у невтомності та непримиренності 3 новими порядками. Для Доці ця боротьба набуває особливих жіночих рис: вона підтримує, захищає, витягує з того світу молитвою. Елементом образу війни, який випливає 3 боротьби, є смерть. Мортальність у романі представлена досить широко, авторка вдається до описів понівечених тіл та жорстоких розправ над людьми для гострішого сприйняття читачем цієї сторони війни. Саме смерть $\epsilon$ рушійною силою, яка змушує головну героїню поділити своє життя на «до війни» та «після».

\section{Література:}

1. Горіха Зерня Т. Доця. Київ: Білка, 2019. 284 с.

2. «Доця» - книга, яка назавжди змінить кожного, хто ії прочитає // Армія.fm. URL: https://www.armyfm.com.ua/docya---kniga-yaka-nazavzhdizminit-kozhnogo-hto-ii-prochitaye/

3. Ісусе, синку: «Доця» як месія 3 Донбасу // Читомо. URL: https://chytomo.com/isuse-synku-dotsia-iak-mesiia-z-donbasu/ 